\title{
Naturokultura w powieści Therese Bohman O zmierzchu
}

\section{Abstract}

\section{Natureculture in the Novel Eventide by Therese Bohman}

One of the basic goals of ecocriticism is to deconstruct the binary opposition between "nature" and "culture", so typical of Western thinking, and to show that these two notions are interdependent and cannot be separated. Donna Haraway proposes to reject this dichotomous division in favour of a new term coined by her, that is natureculture.

This article aims at showing how the relationship between "nature" and "culture" is construed in the novel Eventide (2016) by Swedish writer Therese Bohman. The author focuses on the interplay between them and emphasizes the hybrid nature of reality, which could be described as naturalcultural, within the meaning intended by Haraway. Bohman exposes naturalcultural interactions on multiple levels, both diegetic and non-diegetic: starting from the title of her novel, through the imagery in the text, descriptions of the action scene, characters and the observations of the main protagonist, ending with elements of the plot.

Keywords: nature, culture, natureculture, ecocriticism, Donna Haraway, Therese Bohman, Eventide

Słowa kluczowe: natura, kultura, naturokultura, ekokrytyka, Donna Haraway, Therese Bohman, O zmierzchu

We wstępie do swojego wprowadzenia do ekokrytyki pod tytułem Cyborg w ogrodzie Julia Fiedorczuk przypomina: „Najtrwalszym elementem zachodniego myślenia o miejscu człowieka w świecie fizycznym jest wydzielenie odrębnych domen «natury» $\mathrm{i}$ «kultury» i pojmowanie tych domen w kategoriach ściśle

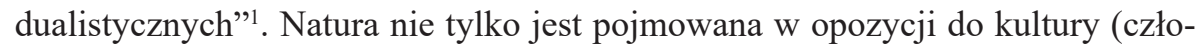

1 J. Fiedorczuk, Cyborg w ogrodzie. Wprowadzenie do ekokrytyki, Gdańsk 2015, s. 34. Por. P. Czapliński, Maszyny znikania, albo jak istnieje to, co nie istnieje [w:] Literatura i jej natury, red. P. Czapliński, J.B. Bednarek, D. Gostyński, Poznań 2017, s. 8. 
wieka, cywilizacji), ale i podporządkowana ich potrzebom² ${ }^{2}$. Do podstawowych celów ekokrytyki zalicza się rozmontowanie tej opozycji ${ }^{3}$ i wskazanie, że natura i kultura są współzależne i nie da się ich oddzielić4.

Refleksja nad konstrukcją pojęć „natura” i „kultura” jest stale obecna w obszarze zainteresowań Donny Haraway ${ }^{5}$. Zdaniem badaczki rozumienie „natury” i ,kultury” jako przeciwnych lub uniwersalnych kategorii jest błędne ${ }^{6}$. Taki sposób postrzegania rzeczywistości Haraway nazywa aktem odziedziczonej przemocy ${ }^{7}$. Odrzucając rozmaite definicje natury, podważa opozycję „natury” i „kultury”. Proponuje posługiwanie się pojęciem naturokultur, pod którym rozumie „implozje dyskursywnych obszarów natury i kultury" raway pisze najwięcej o cyborgach i zwierzętach ${ }^{10}$. W ich przypadku implozja ta jest szczególnie wyraźna ${ }^{11}$. Pojęcie naturokultur nie ogranicza się oczywiście tylko do nich - Haraway zwraca uwagę na „naturokulturowy wymiar naszych codziennych praktyk"12.

Niniejszy artykuł jest próbą ukazania, w jaki sposób relacja między „naturą” i „kulturą” budowana jest w powieści $O$ zmierzchu (2016) ${ }^{13}$ autorstwa szwedzkiej pisarki Therese Bohman. Tekst powieści zrywa z przedstawianiem „natury” i „,kultury” jako binarnych opozycji. Koncentruje się na ich wzajemnym przenikaniu i podkreśla hybrydyczny charakter rzeczywistości, który można określić naturokulturowym w rozumieniu Haraway.

Urodzona w 1978 roku Therese Bohman zadebiutowała jako powieściopisarka w pierwszej dekadzie XXI wieku. O zmierzchu to jej trzecia, najnowsza powieść i jednocześnie pierwsza przetłumaczona na język polski. Główną bohaterką jest czterdziestokilkuletnia Karolina Andersson, profesorka historii sztuki na Uniwersytecie w Sztokholmie. Karolina zakończyła właśnie wieloletni związek,

2 Por. D. Gostyński, Natura [w:] Literatura i jej natury, red. P. Czapliński, J.B. Bednarek, D. Gostyński, Poznań 2017, s. 189.

3 Por. J. Fiedorczuk, op. cit., s. 14.

4 Por. D. Gostyński, op. cit., s.189-190.

5 Por. D. Haraway, How Like a Leaf. An Interview with Thyrza Nichols Goodeve, New York 2000, s. 50.

6 Por. D. Haraway, Manifest gatunków stowarzyszonych [w:] Teorie wywrotowe. Antologia przekładów, przeł. J. Bednarek, Poznań 2012, s. 247.

7 Por. D. Haraway, How Like a Leaf..., s. 106.

8 Por. D. Haraway, Obietnice potworów. Regeneracyjna polityka dla niestosownych/niezawłaszczonych innych (część pierwsza) [w:] Teorie wywrotowe. Antologia przekładów, przeł. A. Kowalcze-Pawlik, Poznań 2012, s. 578-579; por. też M. Bakke, Posthumanizm: człowiek w świecie większym niż ludzki [w:] Człowiek wobec natury - humanizm wobec nauk przyrodniczych, red. J. Sokolski, Warszawa 2010, s. 346-347.

9 D. Haraway, How Like a Leaf..., s. 105.Tu fragment cytatu w thumaczeniu M. Bakke: op. cit., s. 347.

10 Por. D. Haraway, How Like a Leaf..., s. 105-106.

11 Por. M. Bakke, op. cit., s. 347.

12 D. Haraway, Manifest..., s. 248.

13 Por. T. Bohman, Aftonland, Stockholm 2016. W Polsce powieść ukazała się w 2019 roku w Wydawnictwie Pauza, w thumaczeniu Justyny Czechowskiej. Por. T. Bohman, O zmierzchu, Warszawa 2019. 
zamieszkała sama i ma nadzieję na jakiś „,nowy początek”. Zanim to jednak nastąpi, bohaterka przechodzi serię poważnych kryzysów. Narracja w powieści jest trzecioosobowa, prowadzona niezmiennie z perspektywy Karoliny.

Zainteresowanie współistnieniem ,natury” i ,kultury” zostaje zaznaczone już w tytule powieści Bohman. Tytułowy ,zmierzch” może być traktowany jako paratekstualne nawiązanie do ostatniego tomu poetyckiego Pära Lagerkvista $A f$ tonland (1953), wiele wskazuje jednak, że jest to raczej odniesienie do tytułu dwutomowej pracy Oswalda Spenglera Zmierzch Zachodu. Zarys morfologii historii powszechnej ${ }^{14}$, w której autor prezentuje swoją wizję historii. Według niego na historię składa się seria kultur ${ }^{15}$, te zaś filozof pojmuje jako żywe organizmy, przechodzące cykliczne zmiany, przyrównywane do cyklu ludzkiego życia lub pór roku ${ }^{16}$. Teoria Spenglera, krytykowana przez współczesnych jako „generalizując[a] biologii[a] życia historycznego" "17, jest włączana do biologizmu w filozofii ${ }^{18}$. Zwraca w niej uwagę ,prób[a] połączenia różnych porządków: biologicznego i aksjologicznego, historycznego i strukturalnego, życia i wartości, natury i kultury"19. Jako taka jest szczególnie interesująca z posthumanistycznego i ekokrytycznego punktu widzenia. Odnotowywane przez Haraway przykłady naświetlania problemów kultury, historii i polityki przez snucie o nich biologicznych czy ewolucyjnych narracji ${ }^{20}$ znajdują w Zmierzchu Zachodu swój wyraz.

Główna bohaterka powieści $O$ zmierzchu krąży w swoich rozważaniach wokół teorii Spenglera - niewymienionego jednak nigdy w tekście. Karolina myśli o cyklach w sztuce: „Podobała jej się myśl o początkach, rozkwicie i upadku okresów w sztuce, cykliczność była pocieszająca. Zawsze pojawi się coś innego, choć za każdym razem stanie się to w zupełnie nowej formie"21. W zilustrowaniu cyklicznych zmian w sztuce pomaga Karolinie element ze świata nie-ludzkiej przyrody, bohaterka buduje porównanie z życiem tulipanów:

Manieryzm był ostatnim okazałym, pełnym przepychu tchnieniem, w czasie gdy przejmowanie się umiarem nie miało już sensu. Jak gwałtowne więdnięcie bukietu tulipanów:

14 Por. O. Spengler, Der Untergang des Abendlandes. Umrisse einer Morphologie der Weltgeschichte, München 1920-1922. W Polsce dzieło zostało wydane jako Zmierzch Zachodu, por. O. Spengler, Zmierzch Zachodu. Zarys morfologii historii uniwersalnej, przeł. J. Marzęcki, Warszawa 2001. Szwedzki tytuł powieści Bohman, Aftonland, nawiązuje do tytułu prac Spenglera w oryginale. W tłumaczeniu na język szwedzki ukazały się jako Västerlandets undergång, por. O. Spengler, Västerlandets undergång. Konturer till en morfologi om världshistorien, Stockholm 1996-1997. W języku szwedzkim paratekstualne nawiązanie jest zatem nieco mniej wyraźne niż w języku polskim.

15 Por. T. Gadacz, Historia filozofii XX wieku. Nurty, t. 1, Kraków 2009, s. 164; por. też F. Fukuyama, Koniec historii, przeł. T. Bieroń, M. Wichrowski, Kraków 2009, s. 111.

16 Por. T. Gadacz, Historia filozofii XX wieku. Nurty, t. 1..., s. 164.

17 T. Gadacz, Historia filozofii XX wieku. Nurty, t. 2, Kraków 2009, s. 252.

18 Por. T. Gadacz, Historia filozofii XX wieku. Nurty, t. 1..., s. 158; por. też F. Fukuyama, op. cit., s. 111.

19 A. Kołakowski, Wstęp [w:] O. Spengler, Historia, kultura, polityka. Wybór pism, przeł. A. Kołakowski, J. Łoziński Warszawa 1990, s. 8.

20 Por. D. Haraway, How Like a Leaf..., s. 54.

21 T. Bohman, O zmierzchu..., s. 24. 
ostatnia, niepohamowana faza, zanim skurczą się i umrą, stając się wówczas karykaturą tulipanów, podobnie jak manieryzm stał się karykaturą sztuki renesansowej ${ }^{22}$.

Uznanie bukietu tulipanów za przykład ,natury”, wpisanie ich w jedną ze składowych opozycji ,natury” i „,kultury”, byłoby jednak błędnym uproszczeniem. Tulipany, uprawiane w Europie od XVI wieku² ${ }^{23}$, są elementem naturokultury, przykładem gatunków stowarzyszonych w rozumieniu Haraway. Pisząc o gatunkach stowarzyszonych, Haraway ma na myśli ,implozj[e] natury i kultury w nieugięcie swoiste historycznie, wspólne żywoty" przedstawicieli różnych gatunków ${ }^{24}$. Przez gatunki stowarzyszone badaczka rozumie zbiór szerszy niż gatunki towarzyszące. Jako przykłady gatunków stowarzyszonych z ludźmi wymienia ,ryż, pszczoły, tulipany i florę bakteryjną jelit" 25 .

Bukiet tulipanów reprezentuje element naturokulturowej rzeczywistości, za pomocą którego Karolina wyjaśnia rządzące tą rzeczywistością cykliczne zmiany. Myśl o cykliczności towarzyszy bohaterce często. W rozmowie z jednym z kochanków zauważa: ,zmiany mają charakter cykliczny - odparła. - Jak pory roku. Albo style. Teraz mamy jesień, wieczór, manieryzm. Ale pewnego dnia znów będzie wiosna"26.

Sztuka okresu Petrarki to według bohaterki świt, Goethego - dzień. Tytułowy zmierzch oznacza u Bohman, jak u Spenglera, fazę schyłkową. Karolina uzmysławia sobie, że jej życie przypada na okres ,późnego kapitalizmu”27. To określenie na długo przykuwa jej uwagę: ,Zmierzch kapitalizmu, ujrzała to przed sobą: dekadencję poprzedzającą upadek, nieustający wieczór, gdy absurdalne proporcje przybrane przez współczesność rzucają coraz dłuższe cienie"28. Dochodzi jednak do wniosku, że słowo ,zmierzch” jest dużo bardziej pojemne: „może trwa coś więcej niż zmierzch kapitalizmu, może to manierystyczna faza kapitalizmu i może nie dotyczy tylko jego"29. Odnosząc ideę cyklicznych zmian, uznawaną za domenę przyrody ${ }^{30}$, nie tylko do świata natury, ale również sztuki i ekonomii, bohaterka podkreśla naturokulturowy charakter rzeczywistości.

W powieści Bohman jest on także wyraźny na poziomie metaforyki tekstu za sprawą zabiegu, który można nazwać antropomorfizacją à rebours - przez stosowanie zoomorfizacji i fitomorfizacji ${ }^{31}$. Jak zauważa Anna Salomonsson, człowiek

22 Ibid.

23 Por. T. Zioło-Skałecka, Tulipan [w:] Wielka Encyklopedia PWN, t. 28, Warszawa 2005, s. 101.

24 D. Haraway, Manifest..., s. 252.

25 Ibid., s. 251.

26 T. Bohman, O zmierzchu..., s. 105.

27 Ibid., s. 24.

28 Ibid.

29 Ibid., s. 25.

30 Por. M. Mejor, Historia naturalna $w$ dziełach polsko-łacińskich poetów humanistycznych. Zarys problemu [w:] Człowiek wobec natury-humanizm wobec nauk przyrodniczych, red. J. Sokolski, Warszawa 2010, s. 56.

31 Wydaje się, że fitomorfizacja, czyli - przez analogię do antropomorfizacji i zoomorfizacji przypisanie ludziom cech właściwych roślinom, jest terminem rzadko stosowanym w poetyce. Spośród trzech wyżej wymienionych terminów tylko antropomorfizacja figuruje w popularnym Słowniku terminów literackich, por. A. Okopień-Sławińska, Antropomorfizacja [w:] Słownik terminów literackich, 
jest w ujęciu stereotypowym porównywany ze zwierzęciem (zoomorfizacja) w celu przekazania pejoratywnego znaczenia, zwierzę zaś i inne elementy świata nie-ludzkiej przyrody opisywane są przez cechy kojarzone z człowiekiem (antropomorfizacja) i wtedy konstruowane jest znaczenie pozytywne ${ }^{32}$. U podstaw obu chwytów leży ,,antropocentryczna logika”, uznająca nadrzędność pozycji człowieka ${ }^{33}$.

Bohman zrywa z takim ujęciem. W tekście $O$ zmierzchu zawracają uwagę przypadki, w których postacie ludzkie, w utartych dychotomiach, lokalizowane w obszarze kultury i cywilizacji, opisywane są z wykorzystaniem określeń ze świata nie-ludzkiej przyrody, czyli z opozycyjnego obszaru ,natury”. Co ciekawe, to właśnie postacie bardzo wyraźnie związane z ,kulturą” - reprezentanci uniwersytetu, nauki i sztuki - zostają jednocześnie ukazane przez autorkę w relacji do świata przyrody. „Natura” służy do opisu „,kultury”, co podkreśla związek człowieka i nie-ludzkiej przyrody i podważa dychotomiczne myślenie. Postacie zostają wpisane zarówno w porządek natury, jak i kultury, ich złożoność zostaje w tekście wyeksponowana.

Jedną z takich postaci jest Peter, starszy kolega Karoliny z wydziału, badacz renesansowych grafik. Peter nosi nazwisko łączące elementy flory i fauny: Tallfalk, czyli w języku szwedzkim „Sosnowy Sokół”. Nazwisko to nie odwołuje się do konkretnego gatunku ptaka, ma typową konstrukcję szwedzkich nazwisk mieszczańskich, chętnie nawiązujących do świata przyrody, zwłaszcza drzew ${ }^{34}$. Istotne jest jednak, że Peter wymyśla takie nazwisko sam i przybiera je na pewnym etapie życia. Uplastycznia nazwisko, projektując dla siebie ekslibris, który z radością prezentuje Karolinie: „drapieżny ptak na drzewie, z przodu gałązka ze szpilkami i szyszkami. - Widzisz? - powiedział pełen entuzjazmu. - Sosnowy sokół"35.

Tak jak w przypadku komentowanych wyżej tulipanów sokół również jest gatunkiem wyraźnie uwikłanym naturokulturowo. To zarówno dziko żyjący ptak, jak i gatunek hodowlany, wykorzystywany przez człowieka do polowań już przed naszą erą ${ }^{36}$, gatunek stowarzyszony w rozumieniu Haraway. Sokół jest też znanym motywem w literaturze i poetyce, wystarczy wspomnieć choćby nowelę Giovanniego Boccaccia pod tym tytułem, będącą punktem wyjścia dla teorii sokoła o kompozycji noweli ${ }^{37}$. Głównej bohaterce podoba się nazwisko kolegi. Łą-

red. J. Sławiński, Warszawa 1998, s. 35. Antropomorfizacja i antropomorfizm oraz zoomorfizm są samodzielnymi hasłami w Wielkiej Encyklopedii Powszechnej PWN (por. Wielka Encyklopedia PWN, t. 2, Warszawa 2001, s. 133-134 oraz Wielka Encyklopedia PWN, t. 30, Warszawa 2005, s. 439), próżno tam jednak szukać fitomorfizmu i fitomorfizacji. Fitomorfizacja jest szczególnie interesująca z posthumanistycznego punktu widzenia, a jej stosowanie warte dalszego zbadania.

32 Por. A. Salomonsson, Människan och skogen [w:] Norrlands litteratur. Ekokritiska perspektiv, red. P. Degerman, A.E. Johansson, A. Öhman, Göteborg 2018, s. 147.

33 Ibid., przekład własny.

34 Por. Förnamn och efternamn, Institutet för språk och folkminnen, https://www.isof.se/om-oss/for-dig-i-skolan/namn-for-dig-i-skolan/fornamn-och-efternamn.html (dostęp: 1.02.2020); por. także M. Zaremba Bielawski, Leśna mafia. Szwedzki thriller ekologiczny, Warszawa 2014, s. 22-23.

35 T. Bohman, O zmierzchu..., s. 53.

36 Por. Wielka Encyklopedia PWN, t. 25, Warszawa 2004, s. 335-336.

37 Por. M. Głowiński, Sokoła teoria [w:] Słownik terminów literackich, red. J. Sławiński, Warszawa 1998, s. 517. 
czy według niej elegancję i konotacje z literaturą dziecięcą. Zbudowane z członu odwołującego się do gatunków drzewa i ptaka budzi niespodziewanie skojarzenia z kulturą. Opisu Petera Tallfalka dopełnia zoomorfizacja. Karolina nie wiąże postaci kolegi akurat z drapieżnym ptakiem: „Miał wygląd myszy, był raczej gryzoniem niż sokołem"38.

Opisując bohaterów, Bohman częściej czerpie jednak ze świata roślin, stosując chwyt fitomorfizacji. Doktorant Karoliny, Anton, budzi jej zainteresowanie między innymi z powodu zapachu. Po raz pierwszy Karolina charakteryzuje zapach jako ,świeży i zielony z odrobiną czegoś słodkiego"39, następnym razem podobnie, jako „lekki i zielony" 40 . Podczas zbliżenia z Antonem czuje ten zapach wyraźniej i próbuje go dookreślić: „Młodość - pomyślała. - Tak pachnie młodość”41. Pokrewne wrażenia wywołuje u niej zapach soku wyciekającego z przycinanej gałązki drzewa figowego: ,Jakby zielony kolor miał zapach. Szorstki i trawiasty, a jednocześnie słodki i mleczny. Może tak pachnie chlorofil. To zapach światła słonecznego, fotosyntezy, ba, samego życia"42. Zapach ciała kochanka i zapach soków roślinnych przypominają o sobie nawzajem i kojarzą się z żywotnością, biologiczną siłą.

Autorka używa zoomorfizacji i fitomorfizacji do opisu bliskich bohaterce postaci. Peter należy do ulubionych kolegów Karoliny, z Antonem łączy ją fascynacja i przelotny romans. W obydwu przypadkach odniesienia do świata fauny i flory niosą pozytywne znaczenie.

Po raz kolejny fitomorfizacja pojawia się w tekście za sprawą Petera, gdy ten opisuje siebie i Karolinę: ,Jesteśmy late bloomers, ty i ja - odezwał się Peter. Jak najlepsi ludzie"43. Angielskie określenie oznacza późno kwitnące rośliny, metaforycznie zaś osoby, które późno dojrzewają ${ }^{44}$. Dosłowne znaczenie użytego przez Petera sformułowania przypomina o sobie podczas wieczoru, który Karolina spędza z nim i jego żoną Leylą w ich ogrodzie, w otoczeniu późnych kwiatów:

Wokół nich kwitły jesienne anemony i astry, ostatni oddech lata. Astry Petera i Leyli nie były blade, ale wiśniowe i fioletowe, i choć w ciemności wyglądały na niemal czarne, można się było domyślić ich nasyconych kolorów - cokolwiek miały oznaczać, lato minęło.

Bezsensowne jest kwitnienie o tej porze roku, to wzniosła bezsensowność, choć przez to wcale nie mniej bez znaczenia ${ }^{45}$.

Kwitnące u schyłku lata rośliny są na pierwszy rzut oka zjawiskiem pozbawionym większego sensu. Jednocześnie bohaterka nie może nie zauważyć intensywnych barw astrów ani odmówić kwiatom wzniosłości. Podobnie ambiwalentne uczucia ma wówczas wobec własnej egzystencji.

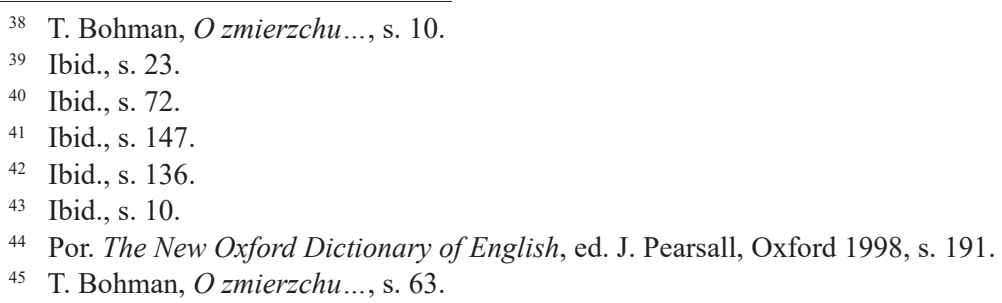


Zabieg fitomorfizacji powraca w autorefleksjach Karoliny, tym razem niosąc jednoznacznie pozytywne znaczenie. W apogeum kryzysów bohaterka rozmyśla o banku nasion, który jest dla roślin gwarancją odrodzenia po kataklizmach. To kolejny przykład złożonych naturokulturowych związków. Idea cywilizacji ratującej przyrodę nie jest nowa, bohaterka porównuje bank z biblijną arką Noego. Od ogólnej refleksji o zabezpieczeniu przyszłości roślin Karolina przechodzi do swojej jednostkowej sytuacji. Chciałaby, by i dla niej istniało podobne rozwiązanie: „Zamknijcie mnie w banku nasion na Spitsbergenie - pomyślała. - I nie wypuszczajcie, dopóki nie będę w stanie normalnie żyć" ${ }^{46}$. Od banku nasion rozważania bohaterki wędrują do jednego konkretnego gatunku, do bodziszka:

Niektóre rośliny same tworzą banki nasion - to fascynujące. Nasiona bodziszków na przykład kiełkują dopiero po pożarze lasu: przelegują w ziemi i aktywują się od gorąca w glebie, gdy w lesie szaleje ogień. Nie wiadomo, jak długo mogą tak czekać w ziemi, ale znaleziono zdolne do kiełkowania nasiona tam, gdzie nie paliło się od kilkuset lat ${ }^{47}$.

Powoli pokonując kryzysy, Karolina dochodzi do wniosku, że samą siebie może postrzegać właśnie jako bodziszka: «A może to jest mój pożar lasu» - pomyślała. Cała ta jesień, wydłużony, powolny chrzest ogniowy. Ale to jej nie załamie, nawet jeśli jeszcze niedawno odnosiła takie wrażenie. Miała wyjść z tej historii gotowa na coś nowego, niczym bodziszek" ${ }^{\text {"48 }}$. Bohman po raz kolejny podważa antropocentryczny porządek. Przewaga roślin nad człowiekiem jest wyraź$\mathrm{na}^{49}$. Ich przetrwaniu sprzyja nie tylko arktyczny chłód Spitsbergenu, ale i ogień pożarów. Dla bohaterki odwołanie do świata roślin staje się ostatecznie źródłem optymizmu.

Innym przykładem nierozerwalnego związku „natury” i „kultury” jest w powieści Bohman konkretna, wielokrotnie przywoływana przestrzeń - Muzeum Historii Naturalnej. Już sama dyscyplina - historia naturalna - świadczy o współistnieniu „natury” i „kultury”. Przychodzi tu również na myśl spostrzeżenie Haraway, że „[n]atura nie może przedistnieć aktu swego stworzenia, swojej konstrukcji” ${ }^{\circ 0}$, „natura” istnieje opisywana przez „kulturę”.

Historia naturalna formułuje się w okresie renesansu. Jak przypomina Jacek Sokolski, „,[w] drugiej połowie XVI wieku przekonanie, iż problematyka przyrodnicza jest pełnoprawnym składnikiem humanistycznej refleksji i humanistycznej twórczości, stało się powszechne" ${ }^{15}$. W takich warunkach powstaje historia naturalna jako dyscyplina naukowa, która zajmuje się przyrodniczymi faktami:

46 Ibid., s. 188.

47 Ibid.

48 Ibid., s. 204.

49 Temat jest obecny w posthumanistycznej refleksji. Porusza go m.in. Anna Nacher: „Zdaniem badaczy rośliny przyjęły odmienną strategię przetrwania i [...] być może jest to strategia znacznie skuteczniejsza niż zwierzęca, nie mówiąc o ludzkiej”. Por. A. Nacher, Las - wspólnota sympoietyczna?, „Czas Kultury” 2017, nr 3, s. 10.

50 D. Haraway, Obietnice potworów..., s. 579.

51 J. Sokolski, Natura lubi się ukrywać [w:] Człowiek wobec natury - humanizm wobec nauk przyrodniczych, red. J. Sokolski, Warszawa 2010, s. 27. Por. także J. Sokolski Wstęp [w:] Człowiek wobec natury - humanizm wobec nauk przyrodniczych, red. J. Sokolski, Warszawa 2010, s. 9-10. 
„Porządek natury i porządek kultury przenikają się tutaj nawzajem, nawet przyjęte przez autorów zasady klasyfikacji odwołują się często do systemów wartości zaczerpniętych ze świata ludzi" ${ }^{52}$. Na marginesie: to właśnie do renesansu główna bohaterka powieści ma szczególny, afirmatywny stosunek.

Już od pierwszych stron powieści zwraca uwagę wyjątkowe zainteresowanie Karoliny, historyczki sztuki, Muzeum Historii Naturalnej. Obserwuje jego budynek ze swojego gabinetu na uniwersytecie. Początkowo muzeum zdaje się stanowić dla Karoliny domenę ,natury”, w opozycji do „kultury”, w tym sztuki, po której bohaterka porusza się zawodowo i której ramy odczuwa jako zbyt ciasne. Poczucie zamknięcia w jednym $\mathrm{z}$ dwóch dychotomicznych obszarów, w sztuce, nabiera u Karoliny wręcz fizycznego charakteru: „W gabinecie było duszno, na chybił trafił przekręciła gałkę klimatyzatora, a może grzejnika, nie potrafiła się połapać, czy ten sprzęt w ogóle działa. Otworzyła okno. Widziała przez nie Muzeum Historii Naturalnej, budynek, którego widok nigdy się jej nie znudził. [...] Z pewnością panuje tam przyjemny chłód"53.

Muzeum oferuje inną perspektywę, z którą Karolina od dawna nie ma łączności. Na próżno próbuje sobie przypomnieć, kiedy ostatni raz odwiedzała muzeum - 10, 15, 20 lat temu? Uświadamia sobie, że było to więcej niż 20 lat temu, raczej 25. Traktowaniu „kultury” i „natury” jako odrębnych obszarów bohaterka daje wyraz, kontrastując reprezentujące je siedziby, za jakie uważa odpowiednio uniwersytet i muzeum. Jej gabinet zlokalizowany jest co prawda w jednym $\mathrm{z}$ niewielu przyjaznych wizualnie obiektów uniwersyteckich, wewnątrz nieróżniącym się jednak od innych przestrzeni publicznych, co podkreśla charakterystyczna wykładzina z PCV. Zajęcia odbywają się zaś w jednym z sześciu uniwersyteckich wieżowców, wybudowanych w latach 60 . Karolina źle się w nich czuje, już jako studentka „nie znosiła tam przebywać. Często myślała o tym, jak można było miejscu przeznaczonemu na studiowanie sztuki nadać równie brzydką formę" ${ }^{" 54}$. Budynek muzeum budzi zupełnie inne, pozytywne doznania:

przystanęła przed jego masywną sylwetką. Główna część z kopułą wyglądała imponująco, ale szczególnie ceniła całość: skrzydła, które otaczały podwórze przed muzeum, tworząc w środku przestrzeń. Kiedy tam stała, miała wrażenie, że budynek chce ją objąć, że wyciąga w jej stronę ramiona w miłosnym, lecz wyzywającym geście. Była to budowla, w której miała ochotę modlić się do Boga. Jeśli w jakiegoś by wierzyła ${ }^{55}$.

Na postrzegane osobno „naturę" i „kulturę” nakłada się dodatkowo podział na sacrum i profanum. Czas spędzony w muzeum to dla Karoliny chwile wytchnienia, fizycznego - w budynku muzeum rzeczywiście odczuwa się miły chłód, a posadzka wykonana jest z naturalnego marmuru o różnych odcieniach - i psychicznego:

To przeciwieństwo jej obszaru badań, naukowy porządek w odróżnieniu od sztuki sterowanej emocjami i dekadencji. Przyjazne, pedagogiczne próby wyjaśnienia nazw drzew liściastych i sposobu organizacji mrowiska, zmian pór roku, tego, co po prostu idzie dalej.

\footnotetext{
52 Ibid., s. 30.

53 Ibid., s. 8-9.

54 Ibid., s. 16.

55 Ibid., s. 77-78.
} 
W naturze nie istnieje żaden manieryzm, w każdym razie nie w tej perspektywie czasowej, którą znamy ${ }^{56}$.

Tak jak renesansowi humaniści ${ }^{57}$ Karolina przypisuje naturze racjonalność. Myśl o panującej w przyrodzie harmonii zajmuje bohaterkę najbardziej i jest krzepiąca:

Wszystko jakby wyjęte z książek Elsy Beskow, które tak lubiła w dzieciństwie, poczucie bezpieczeństwa kojarzące się z przedszkolem i pierwszymi latami w szkole, kiedy zdobywała wiedzę o świecie, lecz ten wciąż jawił się jako maleńki, konkretny i zrozumiały. [...] naprawdę czuła się bezpieczna ze względu na panujący tu porządek świata ${ }^{58}$.

Odmienność ,natury” i ,kultury” jest jeszcze w rozważaniach Karoliny obecna. „Cywilizacja” jest brzydka, duszna, nieprzyjazna, powszednia, sterowana emocjami, dekadencka, należy do profanum. „Przyroda” natomiast - piękna, chłodna, przyjazna, uporządkowana, witalna, zlokalizowana w sferze sacrum. Rozłączność ustępuje jednak powoli miejsca współzależności. Naturokulturowy charakter rzeczywistości pobrzmiewa w refleksjach Karoliny coraz wyraźniej: przez skojarzenie ze edukacją muzeum, dotąd postrzegane przez bohaterkę jako reprezentacja „natury”, ujawnia swoją funkcję „,kultury” tworzącej „naturę”.

Skomplikowany związek tego, co „naturalne”, z tym, „co kulturowe”, staje się dla Karoliny widoczny także w muzealnym sklepie, gdzie jej podziw budzą muszle: „Że też natura potrafi stworzyć coś takiego"59. Natura i jej wytwory zbliżają się w tym zachwycie do sztuki i jej dzieł. Muszla budzi natychmiast także skojarzenie z ciałem kobiety. Karolina ,,przesunęła palcem po spirali, która była coraz gęstsza i węższa ku wierzchołkowi, a ten przypominał brodawkę piersi. Ba, cała muszla wydawała się esencją kobiecego ciała, lekko połyskujące perłowe otwarcie, piersi i macica w jednym przedmiocie" ${ }^{90}$. Tak jak w przypadku zoomorficznych i fitomorficznych chwytów antropocentryczny porządek ustępuje miejsca naturokulturowej złożoności - z jednej strony opis muszli jest antropomorficzny, z drugiej, dla wyrażenia esencji kobiecego ciała, zostaje wykorzystany element ze świata nie-ludzkiej przyrody.

Muszlę i zakupione w muzeum kamienie Karolina układa na parapecie swojego gabinetu. Dekoracja, która w ten sposób powstaje, to „,[n]iewielka naukowa martwa natura, a może jakiś ołtarzyk, zbiór reliktów z Muzeum Historii Naturalnej za oknem jako tłem" ${ }^{61}$. To kolejny przykład naturokulturowego splątania. Elementy „naturalne”, muszle i kamienie, trafiają do muzeum, gdzie jako wystawione na sprzedaż pamiątki wchodzą do obiegu „kultury”. Jako „martwa natura”, opisana przymiotnikiem „naukowa”, oraz jako „ołtarzyk”, ale także „relikty”, funkcjonują w gabinecie Karoliny w podwójnej roli, są reprezentacjami „,natury” i „kultury”, sfer sacrum i profanum. Potrzebę poczucia naturokulturowego kontinuum pod-

\footnotetext{
56 Ibid.

57 Por. J. Sokolski, Wstepp..., s. 10.

58 T. Bohman, $O$ zmierzchu..., s. 78.

59 Ibid., s. 81.

60 Ibid.

61 Ibid., s. 85.
} 
kreśla fakt, że dekoracja Karoliny to namacalne wspomnienie wnętrz Muzeum Historii Naturalnej, które „[o] dziwo, bardzo poprawiło jej [...] humor”62.

Opozycja „natury” i „kultury”, której potwierdzenie Karolina dostrzegała wcześniej w kontraście między budynkami wydziału i muzeum, na ostatnich stronach powieści jest już nieobecna. W jesiennym słońcu Karolina dostrzega piękno wieżowców uniwersyteckich, które mienią się kolorami „niczym szlachetne kamienie, miasto szmaragdów" ${ }^{63}$. Skojarzenie jest naturokulturowe - wytwory cywilizacji, budynki, bohaterka porównuje do elementów ze świata przyrody, minerałów. Te ,naturalne” elementy, szmaragdy, zostają ze względu na swoje właściwości wyróżnione w praktykach kulturowych i określone mianem „szlachetnych”. Gdy w ostatniej scenie Karolina zmierza do budynku muzeum, tekst eksponuje raczej pokrewność tych miejsc, którą w przestrzeni dodatkowo podkreśla łączący je rząd drzew: „Niebo było jasne, strzeliste topole między uniwersytetem a muzeum stały niczym wysokie żółte płomienie na tle ciemnego błękitu" ${ }^{64}$. Ostatnie spojrzenie Karolina kieruje na budynek muzeum, w którym podobnie jak w wieżowcach wydziału manifestuje się nierozerwalny związek „natury” i „kultury”:

Przystanęła na ogromnym placu przed muzeum, naprzeciwko głównego wejścia, przyglądała się wielkiej budowli. Naprawdę wyglądała jak organizm, teraz wyraźnie to widziała, ciało z kopułą jak głowa pośrodku. Przypominała mozaikę na ścianie w głównej sali parafialnej zboru w Gusum [...]: stylizowana na lata siedemdziesiąte wersja Jezusa wyciągającego ramiona, który obiecywał, że przytuli każdego, kto zechce do niego podejśćc5.

Sylwetka muzeum wywołuje ciąg skojarzeń, w których następuje przejście od anonimowego organizmu do wyobrażenia konkretnej postaci, przedstawionej z charakterystyczną manierą, w konkretnym dziele sztuki. W oczach bohaterki Muzeum Historii Naturalnej staje się naturokulturową hybrydą.

„Natura” przestaje być opozycją do zainteresowań badawczych Karoliny, sukcesywnie staje się ich częścią. U progu kariery akademickiej bohaterka zajmowała się kobietami w szwedzkim malarstwie przełomu XIX i XX wieku. Wśród badanych przez nią motywów są zarówno kobieta jako matka i femme fatale, kobieta jako natura, kobieta jako wampir i kobieta ze zwierzętami. Te motywy prowadzą Karolinę do kolejnego projektu badawczego, który dotyczy zwierząt w sztuce.

W swojej pracy bohaterka coraz silniej akcentuje naturokulturowy charakter rzeczywistości. Badając przedstawienia zwierząt, Karolina skupia się na małpach. Podkreśla ich znaczenie dla różnych dyscyplin naukowych: „małpa pojawia się we wszystkich kluczowych kwestiach, jakimi w ogóle można się dziś zająć na uniwersytecie: płeć i klasa, etniczność i seksualność" ${ }^{66}$. Wnioski bohaterki odsyłają niemal wprost do Haraway, która opowiadając o swoim zainteresowaniu naczelnymi, stwierdza: ,arguments from nature are absolutely central to race and

\footnotetext{
62 Ibid.

63 Ibid., s. 197.

64 Ibid., s. 204.

65 Ibid.

66 Ibid., s. 32.
} 
gender debates, and class debates for that matter"67. Karolina dostrzega, że figura małpy podważa binarne podziały: „Małpa znajdowała się w potwornej strefie granicznej między kategoriami «zwierzę i człowiek», «natura i kultura», «cywilizacja i dekadencja»" $"{ }^{\prime 6}$. Porównując przedstawienia małp u Pietera Bruegla i na obrazach Gabriela von Maxa, bohaterka $\mathrm{z}$ łatwością zauważa, jak upowszechnienie darwinizmu wpływa na zmianę znaczenia małpy w sztuce. W pasji Karoliny po raz kolejny daje o sobie znać nierozłączność „,natury” i ,kultury”. Nowy projekt oferuje bohaterce możliwość wyjścia, tak pożądaną, poza dotychczasowy, ograniczający ją obszar badań: „Jej poszukiwania małpich motywów sprowadzały ją na najróżniejsze boczne drogi. Nie do końca wiedząc, jak to się stało, niebawem porzuciła sztukę i z wielkim zainteresowaniem zaczęła czytać artykuły naukowe"69.

Tak Karolina natrafia na postać rosyjskiego biologa Ilji Iwanowa i jego projekt. Badacz zaczyna od prób łączenia bydła i koni wyścigowych, by wkrótce zamarzyć o przekroczeniu granicy między tym, co ludzkie i nie-ludzkie - jego celem jest stworzenie hybrydy człowieka i małpy. W laboratorium Iwanowa „zanika granica między zwierzęciem a człowiekiem, między ludzkim rozumieniem natury a kulturą, ostatnie podstawowe tabu, które niebawem okaże się niczym więcej jak wyobrażeniem w ograniczonych mózgach"70. Karolina poświęca na poszukiwanie informacji o projekcie Iwanowa wiele czasu, a nawet buduje w wyobraźni hipotetyczne losy zaangażowanej w jego badania anonimowej Rosjanki.

Wyraźne naturokulturowe cechy noszą także opisywane przez Bohman krajobrazy.

Tak jest w przypadku rodzinnego miasteczka Karoliny, niewielkiego Gusum. To dawna miejscowość przemysłowa, w której produkcja odbywała się od XVII wieku - najpierw wytwarzano tam mosiądz, potem zamki błyskawiczne. Pod koniec XX wieku zakłady zostały zamknięte. Jednocześnie odkryto katastrofalny wpływ ludzkiej działalności na środowisko - okazało się, że do pobliskiej rzeki Gusumån przez dziesiątki lat trafiały przemysłowe zanieczyszczenia: „Toksyczne ścieki całkowicie uśmierciły naturę wokół Gusum, ziemia wyjałowiała, nieszczęsne pnie drzew sterczały bez liści"’11.

Elementy „naturalne” i „kulturowe” pozostają w nierozerwalnym związku również w codziennych rozważaniach Karoliny. Swoje doświadczenie zagłady miejscowej natury Karolina wyraża, uciekając się do kulturowych kodów. Gusum można zadaniem bohaterki dobrze opisać określeniem „szwedzki Czarnobyl w małej skali" 72 i wezwaniem, zaczerpniętym z Boskiej komedii, które wyobraża sobie przy wjeździe do miasteczka: „PORZUĆCIE WSZELKĄ NADZIEJĘ, WY, KTÓRZY TU WKRACZACIE”’3. „Natura” i „kultura” wspólistnieją także w ob-

67 D. Haraway, How Like a Leaf..., s. 54, argumenty z obszaru natury są centralne dla debat o rasie, płci [gender] i klasie" (przekład własny).

68 T. Bohman, O zmierzchu..., s. 32.

69 Ibid., s. 87.

70 Ibid., s. 88-89.

71 Ibid., s. 126.

72 Ibid.

73 Ibid. 
serwacjach bohaterki dotyczących dzikich roślin w pobliżu jej rodzinnego domu. Zapach bylicy przywodzi jej na myśl piołun, a ten z kolei - doprawiany nim alkohol, absynt. Stąd tylko krok do całej sieci kulturowo uwarunkowanych skojarzeń:

Les fleurs du mal. To nie stąd miejscowy malört, czyli piołun, wziął swoją nazwę; uważano, że chroni przed molami, po szwedzku mal, ale i tak logiczny był symboliczny związek: „A imię gwiazdy tej zowie się Piołun” - jak głosi Apokalipsa. Gwiazda, która spadła z niego [sic! $]^{74}$ i zatruła wodę tak, że ludzie umierali ${ }^{75}$.

Skojarzenie z Kwiatami zła Charles'a Baudelaire'a i fragmentem Apokalipsy św. Jana, dotyczącym otwarcia siódmej pieczęci (Ap. 8,11), prowadzi z powrotem do kataklizmu w rodzinnym miasteczku. Bohaterka zastanawia się, ile ofiar przyniósł w Gusum ,wyciek szwedzkiego Czarnobyla"76.

Wielkomiejska sceneria Sztokholmu to również przykład krajobrazu o silnie zaznaczonym naturokulturowym charakterze. Interakcje „natury” i „kultury” są wyraźne w opisie wzgórza Hammarby. Mocno przekształcone przez człowieka, zostaje odzyskane przez przyrodę:

Usypano je z mas ziemi pochodzących z budowy Globen i dzielnicy Hammarby Sjöstad. To siedlisko ruderalne, miejsce będące wynikiem działalności człowieka: wysypiska śmieci, rozkopane szyby i tereny fabryczne, biotop stworzony przez człowieka, ale na powrót wchłonięty w nieubłagany obieg natury, na którym pojawia się najdziwaczniejsza flora: pośród trawy, chwastów i chaszczy mogło wyrosnąć cokolwiek, coś, co znalazło się tam w formie odpadu, ale dobrze czuło się w tej ziemi. Zdziczałe rośliny ogrodowe, słoneczniki i pomidory, także egzotyczne palmy daktylowe i drzewka awokado potrafiły wystrzelić w tej ekologicznej wolnej strefie, jaką stanowiła strefa poprzemysłowa. Brzydka przyroda, ale żywotna ${ }^{77}$.

Wartościujące określenie podsumowujące opis - „brzydka przyroda” - to kolejny ślad „kultury” opowiadającej „naturę”. W tym przypadku nie jedyny. Hammarby, oglądane przez Karolinę z dystansu, budzi skojarzenia z malarstwem, „błękitnieje po drugiej stronie wody jak na renesansowym obrazie" ${ }^{78}$. Kulturowy filtr sprawia, że estetyczna wartość wzgórza rośnie.

Bohaterka dostrzega przy tym kolejne podobieństwo między Hammarby a renesansowymi obrazami - sztuczność:

W tym sensie wzgórze Hammarby było dalekie od oszałamiająco pięknych gór renesansowych, choć tamte też były sztuczne. Szczyty górskie u Bruegla nie istniały w holenderskim krajobrazie. Widział je w młodości we Włoszech, do zaśnieżonego holenderskiego pejzażu przemycił kawałek Palermo, Neapolu i Rzymu ${ }^{79}$.

Zarówno miejska sceneria Hammarby, jak i pejzaże w malarstwie Bruegla to skomplikowane naturokulturowe hybrydy. W procesie ich powstawania udział

74 W oryginale: „Stjärnan som föll från himlen”, czyli: „Gwiazda, która spadła z nieba”.

Por. T. Bohman, Aftonland..., s. 145.

75 T. Bohman, O zmierzchu ..., s. 131.

76 Ibid.

77 Ibid., s. 156-157.

78 Ibid., s. 156.

79 Ibid., s. 157. 
miały „natura” i „kultura”, występujące jednocześnie w roli elementów tworzonych i tworzących.

Przybliżając teorie Haraway, Joanna Bednarek pisze o codziennym doświadczeniu uwikłanym w naturokulturowe związki ${ }^{80}$. W podobnych słowach podsumowuje propozycje Haraway Monika Bakke, zwracając uwagę na fakt, że „hybrydyczność staje się zwyczajnym sposobem codziennego funkcjonowania"81. W powieści Therese Bohman $O$ zmierzchu to naturokulturowe uwikłanie zostaje szczególnie wyeksponowane na różnych poziomach, diegetycznym i pozadiegetycznym: od tytułu powieści, poprzez metaforykę, opisy miejsca akcji i postaci, spostrzeżenia głównej bohaterki, po elementy fabuły.

Ekokrytyczna lektura powieści Bohman nie kończy się oczywiście na wskazaniu w niej przykładów naturokulturowych interakcji. Stosowanymi przez ekokrytykę pojęciami, przez które można zbliżyć się do tekstu Bohman, są poza tym choćby antropocen i hiperobiekt. Powieść zaprasza ponadto do wielu innych odczytań - jest wdzięcznym polem do analiz intertekstualnych i intermedialnych, do badań z pozycji feministycznych, marksistowskich i geopoetyckich.

\section{Bibliografia}

Bakke M., Posthumanizm: człowiek w świecie większym niż ludzki [w:] Człowiek wobec natury - humanizm wobec nauk przyrodniczych, red. J. Sokolski, Warszawa 2010.

Bednarek J., Powrót „,rzeczywistości” [w:] Teorie wywrotowe. Antologia przekładów, red. A. Gajewska, Poznań 2012.

Bohman T., Aftonland, Stockholm 2016.

Bohman T., O zmierzchu, przeł. J. Czechowska, Warszawa 2019.

Czapliński P., Maszyny znikania, albo jak istnieje to, co nie istnieje [w:] Literatura i jej natury, red. P. Czapliński, J.B. Bednarek, D. Gostyński, Poznań 2017.

Fiedorczuk J., Cyborg w ogrodzie. Wprowadzenie do ekokrytyki, Gdańsk 2015.

Förnamn och efternamn, Institutet för språk och folkminnen, https://www.isof.se/omoss/for-dig-i-skolan/namn-for-dig-i-skolan/fornamn-och-efternamn.html (dostęp: 1.02.2020).

Fukuyama F., Koniec historii, przeł. T. Bieroń, M. Wichrowski, Kraków 2009.

Gadacz T., Historia filozofii XX wieku. Nurty, t. 1, Kraków 2009.

Gadacz T., Historia filozofii XX wieku. Nurty, t. 2, Kraków 2009.

Głowiński M., Sokoła teoria [w:] Słownik terminów literackich, red. J. Sławiński, Warszawa 1998.

Gostyński D., Natura [w:] Literatura i jej natury, red. P. Czapliński, J.B. Bednarek, D. Gostyński, Poznań 2017.

Haraway D., How Like a Leaf. An Interview with Thyrza Nichols Goodeve, New York 2000.

80 Por. J. Bednarek, Powrót „rzeczywistości” [w:] Teorie wywrotowe. Antologia przekładów, red. A. Gajewska, Poznań 2012, s. 231.

${ }^{81}$ M. Bakke, op. cit., s. 349. 
Haraway D., Obietnice potworów. Regeneracyjna polityka dla niestosownych/ niezawłaszczonych innych (część pierwsza) [w:] Teorie wywrotowe. Antologia przekładów, red. A. Gajewska, przeł. A. Kowalcze-Pawlik, Poznań 2012.

Haraway D., Manifest gatunków stowarzyszonych [w:] Teorie wywrotowe. Antologia przekładów, red. A. Gajewska, przeł. J. Bednarek, Poznań 2012.

Kołakowski A., Wstęp [w:] O. Spengler, Historia, kultura, polityka. Wybór pism, Warszawa 1990.

Mejor M., Historia naturalna w dziełach polsko-łacińskich poetów humanistycznych. Zarys problemu [w:] Człowiek wobec natury - humanizm wobec nauk przyrodniczych, red. J. Sokolski, Warszawa 2010.

Nacher A., Las - wspólnota sympoietyczna?, „Czas Kultury” 2017, nr 3.

Okopień-Sławińska A., Antropomorfizacja [w:] Słownik terminów literackich, red. J. Sławiński, Warszawa 1998.

Salomonsson A., Människan och skogen [w:] Norrlands litteratur. Ekokritiska perspektiv, eds. P. Degerman, A.E. Johansson, A. Öhman, Göteborg 2018, s. 135-150.

Sokolski J., Natura lubi się ukrywać [w:] Człowiek wobec natury - humanizm wobec nauk przyrodniczych, red. J. Sokolski, Warszawa 2010.

Sokolski J., Wstęp [w:] Człowiek wobec natury - humanizm wobec nauk przyrodniczych, red. J. Sokolski, Warszawa 2010.

Spengler O., Der Untergang des Abendlandes. Umrisse einer Morphologie der Weltgeschichte, München 1920-1922.

Spengler O., Västerlandets undergång. Konturer till en morfologi om världshistorien, Stockholm 1996-1997.

Spengler O., Zmierzch Zachodu. Zarys morfologii historii uniwersalnej, przeł. J. Marzęcki, Warszawa 2001.

The New Oxford Dictionary of English, ed. J. Pearsall, Oxford 1998.

Wielka Encyklopedia PWN, t. 2, Warszawa 2001.

Wielka Encyklopedia PWN, t. 25, Warszawa 2004.

Wielka Encyklopedia PWN, t. 30, Warszawa 2005.

Zaremba Bielawski M., Leśna mafia. Szwedzki thriller ekologiczny, Warszawa 2014. Zioło-Skałecka T., Tulipan [w:] Wielka Encyklopedia PWN, t. 28, Warszawa 2005. 